\title{
Optimization of the staff number of veterinary specialists of the State Veterinary Service of the subjects of the Russian Federation
}

\author{
Ivan N. Nikitin, Mihail N. Vasiliev*, Aleksandr I. Akmullin, and Elena N. Trofimova \\ Kazan State Academy of Veterinary Medicine named after N. E. Bauman, Kazan, 420029, Russia
}

\begin{abstract}
The staff number of veterinary institutions of the State Veterinary Service of the RSFSR was organised in 1963. It changed and improved many times. In the Russian Federation, it has been significantly reduced, the most significant losses in the number of staff veterinary specialists of the State Veterinary Service of the Russian Federation suffered in 2004, and in the subsequent years, it was partially restored. Despite the measures taken, it does not meet modern requirements for ensuring the veterinary welfare of livestock and other industries. The authors attempt to develop an optimal organizational structure and the staff number of the State Veterinary Service of the Republic of Sakha (Yakutia). The available number of veterinarians and paramedics in this Republic is $66.7 \%$ of the science-based requirement. To organise an optimal structure of the State Veterinary Service of the region, it is necessary to employ an additional 475 veterinary doctors and 232 veterinary paramedics.
\end{abstract}

\section{Introduction}

The staff number of veterinary specialists of the State Veterinary Service in modern Russian Federation constituents was formed in the sixties of the last century following the Resolution of the Council of Ministers of the USSR of September 27, 1963 No. 1020 "On improving Veterinary Affairs and strengthening the State Veterinary Control in the state" [1]. It has changed and improved many times for 57 years. A significant reduction in the staff size of the service occurred in 2004 when the Federal service for veterinary and phytosanitary inspection was organised. In the following years, the local veterinary institutions were partially restored in certain regions of the Russian Federation to provide veterinary services to farmers and private farms of citizens, especially those that are remote from district centres and existing State Veterinary Institutions [2]. Without using science-based recommendations focused on labour standards of veterinary specialists, it is impossible to effectively use the Labour resources of the Service [3-6].
The Department of Veterinary Medicine of the Republic of Sakha (Yakutia), concerned about the lack of organization of the existing structure of the State Veterinary Service of the region, the insufficient provision of its veterinary doctors and paramedics, the low level of veterinary services in some settlements, appealed to the Kazan State Academy of Veterinary Medicine named after N.E. Bauman with a request to develop optimal staffing of the State Veterinary Service of the Republic.

\section{Materials and methods}

The research on the development of the optimal structure and staffing of veterinary specialists of the State Veterinary Service was carried out as instructed by the Department of Veterinary Medicine of the Republic of Sakha (Yakutia). When completing the task, the following directives were taken into account:

- the Law of the Russian Federation of May 14, 1993 No. 4979-1 "On Veterinary Medicine" (amended and augmented);

- the Labour Code of the Russian Federation of December 21, 2001 (amended and augmented);

\footnotetext{
*Corresponding author: mnvasiliev@ mail.ru
} 
- the Recommendations on labour norming of veterinary specialists approved by the Scientific and Technical Council of the Ministry of Agriculture of the Russian Federation of December 26, 2014 [7];

- the Recommendations on labour norming of veterinary specialists to service pets, approved by the Association of practising veterinarians of the Russian Federation of May 16, 2012.

- the Norms of time for providing veterinary service on livestock farms, complexes, poultry farms (1984);

- the Standard norms and the Time standards for providing veterinary service in collective farms and state farms (1984);

- the Time standards for work performed by veterinary laboratories (2004).

Initial data on the number of animals, availability of veterinary institutions and specialists in the Republic are provided by the Department of Veterinary Medicine of the Republic of Sakha (Yakutia).

\section{Research results}

The State Veterinary Service of the Republic of Sakha (Yakutia) makes arrangements for the state task, the paid veterinary services under contracts with consumers of veterinary works (services), and it takes the working time for specialists of the Department of Veterinary Medicine, State Medical and Preventive, Diagnostic, Veterinary and Sanitary Institutions following current legal documents of the Russian Federation.

The research established the following:

- the balance of the annual working time fund for all types of state veterinary institutions;

- the annual demand for operational working time for specialists of the Department of Veterinary Medicine and State Veterinary Institutions of 35 settlements (uluses) of the Republic;

- the annual working time requirement of veterinary specialists for veterinary services of cattle and small cattle, reindeer, horses, pigs, dogs, etc.;

- the staff number of veterinary specialists of the Department of Veterinary Medicine and all institutions (Veterinary Testing Laboratories, Medical and Preventive Institutions, State Laboratories of Veterinary and Sanitary Expertise).

The balance of the annual working time fund for veterinary specialists of the State Veterinary Service of the Republic of Sakha (Yakutia) was determined by taking into account the number of the calendar, working and weekend days under the Labor Code of the Russian Federation, the length of the weekdays, regular and additional vacations, and planned sick absences.

The balance of the annual working time fund is shown in table 1.

It is established that the annual effective working time fund for specialists of the Department of Veterinary Medicine of the Republic, Medical and Preventive Institutions and State Laboratories of Veterinary and Sanitary Expertise in food markets ranges from $1,513.4$ to $1,569.4$ hours. The fluctuations in the annual effective working time fund are caused by the different duration of additional vacations of veterinary specialists, established by the Labor legislation.

The results of studying the annual working time norms for preparatory and final work and other services, regulated breaks and the annual operating fund of working time for specialists of the State Veterinary Institutions of the Republic of Sakha (Yakutia) are presented in table 2.

The annual working time norms for preparatory and final work and other services, regulated breaks for veterinarians range from 228.4 hours in the Department of Veterinary Medicine to 448.9 hours in the Republican Veterinary Testing Laboratory, veterinary paramedics and laboratory assistants - from 251.1 hours in the Veterinary Testing Laboratories of settlements (uluses) to 384.7 hours in Veterinary Institutions of Medical and Preventive Profile.

The annual fund of operating working time for veterinarians ranges from 912.7 hours in the Republican Veterinary Testing Laboratory to 1341 hours in the Department of Veterinary Medicine, veterinary paramedics and laboratory assistants - from 1,090.5 hours in the Republican Veterinary Testing Laboratory to $1,254.9$ hours in the State Laboratories of Veterinary and Sanitary Expertise.

Table 1. The balance of the annual working time fund for veterinary specialists of the Republic of Sakha (Yakutia)

\begin{tabular}{|c|c|c|c|}
\hline \multirow[b]{2}{*}{$\begin{array}{c}\text { The name of } \\
\text { indicators }\end{array}$} & \multicolumn{3}{|c|}{ The number } \\
\hline & $\begin{array}{c}\text { The } \\
\text { Department } \\
\text { of } \\
\text { Veterinary } \\
\text { Medicine }\end{array}$ & $\begin{array}{c}\text { Medical } \\
\text { and Preventive } \\
\text { Institutions, State } \\
\text { Laboratories of } \\
\text { Veterinary and } \\
\text { Sanitary Expertise }\end{array}$ & $\begin{array}{c}\text { Veterinary } \\
\text { Testing } \\
\text { Laboratories }\end{array}$ \\
\hline
\end{tabular}




\begin{tabular}{|c|c|c|c|}
\hline $\begin{array}{l}\text { The number } \\
\text { of calendar } \\
\text { days }\end{array}$ & 365.2 & 365.2 & 365.2 \\
\hline $\begin{array}{l}\text { The number } \\
\text { of weekdays }\end{array}$ & 248.8 & 248.8 & 248.8 \\
\hline $\begin{array}{l}\text { The number } \\
\text { of weekends } \\
\text { and holidays }\end{array}$ & 116.4 & 116.4 & 116.4 \\
\hline $\begin{array}{l}\text { The duration } \\
\text { of the } \\
\text { weekday, in } \\
\text { hours }\end{array}$ & 8.0 & 8.0 & 7.2 \\
\hline $\begin{array}{l}\text { The number } \\
\text { of working } \\
\text { hours per year }\end{array}$ & $1,985.4$ & $1,985.4$ & $1,786.4$ \\
\hline $\begin{array}{l}\text { Planned } \\
\text { absences from } \\
\text { work (days): } \\
\text { - annual } \\
\text { holiday } \\
\text { - additional } \\
\text { holiday } \\
\text { - sick absence }\end{array}$ & $\begin{array}{c}28 \\
33 \\
7 \\
\end{array}$ & $\begin{array}{c}28 \\
44 \\
7 \\
\end{array}$ & $\begin{array}{c}28 \\
44 \\
7 \\
\end{array}$ \\
\hline $\begin{array}{l}\text { The number } \\
\text { of non- } \\
\text { working hours } \\
\text { due to } \\
\text { absences from } \\
\text { work }\end{array}$ & 416 & 472 & 424.8 \\
\hline $\begin{array}{l}\text { The annual } \\
\text { effective } \\
\text { working time } \\
\text { fund, in hours. }\end{array}$ & $1,569.4$ & $1,513.4$ & $1,361.6$ \\
\hline
\end{tabular}

The annual working time requirement for specialists of the Department of Veterinary Medicine of the Republic of Sakha (Yakutia) is shown in table 3.

It is established that the main powers and functions of the Department of Veterinary Medicine require working time in the amount of 13,441 hours, including the working with veterinary reporting documents $67.9 \%$, planning veterinary services, the required calculations for biopreparations, medicines to implement the annual volume of anti-epizootic, therapeutic, veterinary and sanitary measures - 17.2, participation in national agricultural exhibitions - 0.2 , preparation of draft regulatory and legal documents on veterinary issues - 1.4 , concluding agreements, making meetings and performing other activities - 6.8 and monitoring the epizootic condition of the territory of the Republic $-6.5 \%$.

Table 2. The annual working time norms for preparatory and final work and other services, regulated breaks and the annual fund of operating time of the employees of the State Veterinary Service of the Republic of Sakha (Yakutia), in hours.

\begin{tabular}{|l|c|c|c|c|}
\hline & \multicolumn{2}{|c|}{$\begin{array}{c}\text { The annual } \\
\text { working hours for } \\
\text { preparation and } \\
\text { The names of } \\
\text { veterinary } \\
\text { institutions and } \\
\text { executive } \\
\text { services and } \\
\text { authorities } \\
\text { regulated breaks }\end{array}$} & $\begin{array}{c}\text { The annual fund of } \\
\text { Therational working } \\
\text { time of }\end{array}$ \\
\cline { 2 - 5 } & $\begin{array}{c}\text { veteri- } \\
\text { nary } \\
\text { doctor }\end{array}$ & $\begin{array}{c}\text { veteri- } \\
\text { nary } \\
\text { para- } \\
\text { medics }\end{array}$ & $\begin{array}{c}\text { veterinary } \\
\text { doctor }\end{array}$ & $\begin{array}{c}\text { veterinary } \\
\text { para- } \\
\text { medics }\end{array}$ \\
\hline $\begin{array}{l}\text { Medical and } \\
\text { Preventive } \\
\text { Institutions }\end{array}$ & 383.1 & 384.7 & $1,130.3$ & $1,128.7$ \\
\hline $\begin{array}{l}\text { Veterinary } \\
\text { Testing } \\
\text { Laboratories of } \\
\text { uluses }\end{array}$ & 319.9 & 251.1 & $1,041.7$ & $1,110.5$ \\
\hline $\begin{array}{l}\text { Republican } \\
\text { Veterinary } \\
\text { Research } \\
\text { Laboratory }\end{array}$ & 448.9 & 271.1 & 912.7 & $1,090.5$ \\
\hline $\begin{array}{l}\text { State } \\
\text { Laboratories of } \\
\begin{array}{l}\text { Veterinary and } \\
\text { Sanitary } \\
\text { Expertise }\end{array}\end{array}$ & 247.8 & 258.7 & $1,265.6$ & $1,254.9$ \\
\hline $\begin{array}{l}\text { The Department } \\
\text { of Veterinary } \\
\text { Medicine }\end{array}$ & 228.4 & - & $1,341.0$ & - \\
\hline
\end{tabular}

Table 3. The annual working time requirement for specialists of the Department of Veterinary Medicine of the Republic of Sakha (Yakutia)

\begin{tabular}{|l|c|}
\hline \multicolumn{1}{|c|}{ Type of services } & $\begin{array}{c}\text { The amount of } \\
\text { working time, in } \\
\text { hours }\end{array}$ \\
\hline Monitoring of an epizootic situation & 876 \\
\hline $\begin{array}{l}\text { Planning of veterinary arrangements, the } \\
\text { required calculations for veterinary } \\
\text { drugs }\end{array}$ & 2,301 \\
\hline $\begin{array}{l}\text { Working with veterinary reports of } \\
\text { uluses and making summary reports }\end{array}$ & 9,124 \\
\hline $\begin{array}{l}\text { Preparation of draft regulatory and legal } \\
\text { documents on veterinary issues }\end{array}$ & 192 \\
\hline $\begin{array}{l}\text { Conclusion of agreements, making } \\
\text { meetings, and performing other } \\
\text { activities }\end{array}$ & 916 \\
\hline $\begin{array}{l}\text { Participation in exhibitions of animals, } \\
\text { products and raw materials }\end{array}$ & 32 \\
\hline Total & 13,441 \\
\hline
\end{tabular}

Based on the annual fund of operational working hours for specialists of the Department of Veterinary Medicine, it is recommended the Department of Veterinary Medicine of the Republic of Sakha (Yakutia) to have a staff of 10 people to effectively perform this amount of work.

When calculating the need for working time for veterinary care of different types of animals, we used the developed enlarged labour costs per animal, set individually for 
the conditions of the Republic of Sakha (Yakutia):

- cattle - 4.1 hours;

- deer - 2.4 hours;

- horses - 2.2 hours;

- swine - 1.4 hours;

- small cattle - 1.12 hours;

- dogs and other pets - 0.7 hours;

- poultry - 0.15 hours.

The calculation of working time requirements for veterinary services of animals in the settlements (uluses) of the Republic of Sakha (Yakutia) on the example of the city of Yakutsk is presented in table 4.

The calculation used the population of the main types of animals contained in livestock farms, peasant (farmer) and individual subsidiary farms of citizens of the region (cattle, deer, horses, swine, small cattle, pets and poultry).

Table 4. The calculation of working time requirements for veterinary services of animals in the city of Yakutsk of the Republic of Sakha (Yakutia)

\begin{tabular}{|c|c|c|}
\hline Type of animal & $\begin{array}{c}\text { The number } \\
\text { of animals, } \\
\text { in heads }\end{array}$ & $\begin{array}{c}\text { The cost of working } \\
\text { time for veterinary } \\
\text { services, in hours }\end{array}$ \\
\hline Cattle & 3,830 & $15,703.0$ \\
\hline Deer & 7 & 16.8 \\
\hline Horses & 3,549 & $7,807.8$ \\
\hline Swine & 10620 & 14868.0 \\
\hline Small cattle & 413 & 462.56 \\
\hline $\begin{array}{c}\text { Dogs and other } \\
\text { pets }\end{array}$ & 7,532 & $5,272.4$ \\
\hline Poultry & 329,965 & $49,494.75$ \\
\hline Total & & $93,625.31$ \\
\hline
\end{tabular}

The calculation of the recommended staff number of veterinary specialists of animals in the uluses of the Republic of Sakha (Yakutia) on the example of the city of Yakutsk is presented in table 5.

To determine the recommended staff number of veterinary specialists in uluses, the distribution of working hours for veterinary services of animals between the corresponding categories of veterinary specialists was carried out in proportion to the existing staff of veterinary doctors and paramedics in a particular settlement (ulus).

According to the results of calculations, the total need for veterinary specialists in the uluses of the Republic of Sakha (Yakutia) was 1,859 people, including veterinary doctors - 1,267, veterinary paramedics - 592.

When calculating the need for working time for various types of veterinary laboratory research and veterinary and sanitary examination, it was used the developed enlarged labour cost standards per study (examination):

Laboratory research:

- bacteriological (the pathological material) - $140.3 \mathrm{~min}$;

- bacteriological (the product) - $29.8 \mathrm{~min}$;

- serological - $2.6 \mathrm{~min}$;

- virological - $74.0 \mathrm{~min}$;

- histological - $111.0 \mathrm{~min}$;

- haematological - $16.0 \mathrm{~min}$;

- chemical and toxicological - $75.5 \mathrm{~min}$;

- sanitary and zoo-hygienic - $28.4 \mathrm{~min}$;

- pathoanatomical - $98.0 \mathrm{~min}$;

- parasitological - $7.8 \mathrm{~min}$;

- radiological - $41.0 \mathrm{~min}$.

Veterinary and sanitary expertise:

- beef $-29.25 \mathrm{~min}$;

- pork - $39.25 \mathrm{~min}$

- horse meat $-29.25 \mathrm{~min}$;

- lamb, goat - $23.75 \mathrm{~min}$;

- venison - $29.25 \mathrm{~min}$

- poultry meat - $13.89 \mathrm{~min}$;

- eggs, dairy products, honey, fish, fish products, vegetable products $-7.5 \mathrm{~min}$.

Table 5. The calculation of the recommended staff number of veterinary specialists in the city of Yakutsk of the Republic of Sakha (Yakutia)

\begin{tabular}{|c|c|c|c|}
\hline \multirow[b]{2}{*}{ Indicators } & \multirow{2}{*}{$\begin{array}{c}\text { Total } \\
\text { veterinary } \\
\text { specialists } \\
\end{array}$} & \multicolumn{2}{|c|}{ Including: } \\
\hline & & $\begin{array}{c}\text { veterinary } \\
\text { doctors }\end{array}$ & $\begin{array}{c}\text { veterinary } \\
\text { paramedics }\end{array}$ \\
\hline $\begin{array}{l}\text { The actual number } \\
\text { of people. }\end{array}$ & 56 & 33 & 23 \\
\hline $\begin{array}{l}\text { The cost of working } \\
\text { time for veterinary } \\
\text { services of animals, } \\
\text { in hours. }\end{array}$ & 93,625 & 63,824 & 29,801 \\
\hline $\begin{array}{l}\text { The recommended } \\
\text { number of staff, } \\
\text { pers. }\end{array}$ & 83 & 56.5 & 26.5 \\
\hline
\end{tabular}

The total need for veterinary specialists in the Veterinary Testing Laboratories of the Republic of Sakha (Yakutia) was 305 people, including veterinary doctors -210 , veterinary laboratory assistants -95 . These indicators also include the need of the Yakut Republican Veterinary Testing Laboratory: a total of 59 veterinary specialists, including veterinary doctors 42 , veterinary laboratory assistants -17 . 
The total need for veterinary specialists in the State Laboratories of Veterinary and Sanitary Expertise of the Republic of Sakha (Yakutia) was 30 people, including veterinary doctors - 21, veterinary laboratory assistants - 9 .

The total number of veterinary specialists in institutions of the State Veterinary Service of the Republic of Sakha (Yakutia) is shown in table 6.

995 veterinarians work in institutions of the State Veterinary Service of the Republic of Sakha (Yakutia), which is $66.7 \%$ of the science-based requirement, including 63.2 $\%$ - in Medical and Preventive Institutions of 35 uluses, 79.8 - in the Veterinary Testing Laboratories, $73.8-$ in the Republican Veterinary Testing Laboratory, 100 - in State Laboratories of Veterinary and Sanitary Expertise and $80 \%$ - at the Department of Veterinary Medicine.

Table 6. The number of veterinary specialists in institutions of the State Veterinary Service of the Republic of Sakha (Yakutia)

\begin{tabular}{|l|c|c|c|c|}
\hline \multirow{2}{*}{$\begin{array}{l}\text { The name of } \\
\text { veterinary } \\
\text { institutions } \\
\text { and executive } \\
\text { authorities }\end{array}$} & \multicolumn{3}{|c|}{ The number of veterinary specialists: } \\
\cline { 2 - 5 } & $\begin{array}{c}\text { veterinary } \\
\text { doctors }\end{array}$ & $\begin{array}{c}\text { veterinary } \\
\text { para- } \\
\text { medics }\end{array}$ & $\begin{array}{c}\text { opterinary } \\
\text { doctors }\end{array}$ & $\begin{array}{c}\text { veterinary } \\
\text { para- } \\
\text { medics }\end{array}$ \\
\cline { 2 - 5 } $\begin{array}{l}\text { The } \\
\text { Department } \\
\text { of Veterinary } \\
\text { Medicine }\end{array}$ & 8 & - & 10 & - \\
\hline $\begin{array}{l}\text { Medical and } \\
\text { Preventive } \\
\text { Institutions }\end{array}$ & 801 & 374 & 1,267 & 592 \\
\hline $\begin{array}{l}\text { The } \\
\text { Republican } \\
\text { Veterinary } \\
\text { Testing } \\
\text { Laboratory }\end{array}$ & 31 & 16 & 42 & 17 \\
\hline $\begin{array}{l}\text { Veterinary } \\
\text { Testing } \\
\text { Laboratories } \\
\text { of uluses }\end{array}$ & 134 & 65 & 168 & 78 \\
\hline $\begin{array}{l}\text { State } \\
\text { Laboratories } \\
\text { of Veterinary } \\
\text { and Sanitary } \\
\text { Expertise }\end{array}$ & 21 & 9 & 21 & 9 \\
\hline Total & 995 & & & 696 \\
\hline
\end{tabular}

464 veterinary assistants and lab technicians work in the State veterinary network of the Republic of Sakha (Yakutia), accounting for science-based needs of 66.7 $\%$, including $63.2 \%$ in hospitals, 83.3 - in the Veterinary Testing Laboratories of uluses, 94.1 -in the Republican Veterinary and Testing Laboratory, $100 \%$ - in the State Laboratories of Veterinary and Sanitary Expertise. To fully meet the scientific needs of the State Veterinary Service of the Republic of Sakha (Yakutia), it is necessary to have an additional 475 veterinary doctors and 232 veterinary paramedics.

\section{Conclusion}

The optimal staff number of veterinary specialists of the State Veterinary Service of the Republic of Sakha (Yakutia), confirmed by scientific research, taking into account the specifics of the Labor Code of the Russian Federation in a specific natural and economic zone of the region in terms of working hours, regular, Northern vacations, abnormal and harmful working conditions, has been transferred to the practice of the Department of Veterinary Medicine of the Republic. By analogy with it, based on scientific labour norms, the optimal structure and staffing of veterinary specialists of the State Veterinary Service Institutions in other regions of the Russian Federation can be developed, which will ensure their compliance with modern requirements for ensuring the veterinary well-being of livestock and other industries in the regions of the country [8-10].

\section{References}

1. P.A. Chulkov, Bull. of Agricult. Sci., 6, 104-110 (1987)

2. I. Nikitin, A. Akmullin, M. Vasiliev, E. Trofimova, N. Nikolaev, P. Shastin, S. Domolazov, Res. J. Pharm., Biol. Chem. Sci.,10(1), 1781-1787 (2019)

3. A. Atanasova, Econ. and Manag. in Agricult., 33, 35-43 (1988)

4. E. Chavlinova, Econ. and Manag. in Agricult., 23, 54-66 (1986)

5. N. Kostadinova, Econ. and Manag. in Agricult., 48, 108-111 (2003)

6. P. Sasidhar, R. Gopal, Rev. Sci. Tech. Off. Int. Epiz.,32, 639-644 (2013)

7. S.G. Dresvyannikova, I.N. Nikitin, E.N. Trofimova, M.N. Vasiliev, The Issues of Normat. and Legal Regulat.n in Veter. Med., 3, 46-50 (2015)

8. A.I. Klyuchnikova, Sci. Notes of Kazan SAVM, 215, 174-178 (2013) 
9. L.Ya. Yushkova, M.A. Amirakov, A.V. Yudakov, B.N. Balyberdin, Veter. Sci., 2, 18-20 (2012)
10. L.Ya. Yushkova, N.A. Donchenko, Innovat. and Food Security, 1, 124-131 (2018) 